\title{
MEASUREMENT OF CHANGE UNDER THE CULTIVATION \\ SYSTEM IN JAVA, 1837-1851*
}

Robert Van Niel

This paper is an attempt to determine some of the social and economic impacts of the Cultivation System in Java through the use of statistical information contained in reports prepared by government officers at the time the System operated. Such information has not hitherto been used in this way. This paper is meant as an exploration of the possible uses of this type of information. The nature of this information, and the fashion in which it is used, will be made clear as the paper progresses.

The Cultivation System was introduced in Java in 1830 with the arrival of its enthusiastic creator, Johannes van den Bosch. In the previous year King William I had charged van den Bosch with putting into operation the scheme he had devised for making the island of Java produce commodities which would be salable on the world markets. ${ }^{1}$ The Netherlands' government had been singularly unsuccessful in extracting profit from Java since its return from British control in 1816. Now van den Bosch's scheme promised to change all that. It was a plan of ingenious simplicity that recommended itself to the King, and van den Bosch had been dispatched to Java as the new Governor-General.

Unlike earlier schemes which viewed the economic productivity of Java in terms either of individual enterprise on the part of the Javanese or of stimulation by European entrepreneurs, van den Bosch's notion was essentially a governmental-administrative enterprise. Traditional patterns of authority, obligation, tribute, and service were to be harnessed into a productive pattern which would be guided by the traditional Javanese administrative elite with some advice and control by a small corps of European administrators. Despite van den Bosch's protestations that participation in the scheme would be completely voluntary on the part of the Javanese villagers, many of his compatriots entertained grave doubts about the freedom of choice which would be allowed under such control in Java. Before he even arrived in Java, van den Bosch was being criticized for

* The collection of the basic data from archives in the Netherlands was made possible by a grant from the Joint Committee on Asian Studies of the ACLSSSRC; assistance in collating and transcribing the information came from the University of Hawaii Research Council; preparation and programming for computerization was assisted by the Social Science Research Institute of the University of Hawaii. I am indebted to Miss Karen Essene for assistance in programming.

1. Van den Bosch's original advice to the King, dated March 6, 1829, is reprinted in an appendix of D. C. Steijn Parvé, Het Koloniaal Monopoliesteisel Getoetst aan Geschiedenis en Staatshuisoudkunde (Za1t-Bomme1: Noman, 1851), pp. 294-328. 
reintroducing the old VOC system of monopoly and rigid mercantile contro1. This criticism was highlighted by the resignation of the Minister of Industry and Colonies, C. Th. Elout, a strong proponent of liberal economic principles. ${ }^{2}$ But van den Bosch's blandishments had persuaded the King that coercion would not be the keystone of the System and that it would provide the long anticipated profits while actually raising the welfare of the Javanese.

Van den Bosch's plan was simply that the Javanese village set aside a portion of its land, normally one-fifth, for the planting and tending of a crop or crops designated by the government. The produce of this portion of the village's land was to be delivered to the government at a fixed price. This price should, according to van den Bosch's calculations, have been sufficient to pay the landrent owed by the entire village. Since the land-rent was normally calculated at two-fifths of the yield of the village's major crop (usua1ly rice), and since van den Bosch constantly asserted that the new crop would require no more work than rice, the logical conclusion was that the village would have more lands for its own use and would benefit from the application of the System. ${ }^{3}$

Van den Bosch also made reference to a commitment of work which the Javanese was expected to devote to the System. The 1 abor component of the plan was most vague. It is generally assumed that this labor would be used in planting, tending, and cutting the crop planted for the government as well as in preparing the land, opening new lands, and extending the areas of irrigated 1and. It would a1so seem that this amount of labor was the equivalent of traditional corvée services. Obligatory labor of various sorts is, and was, a complicated matter in the Javanese context; the exact dimension of the additional or equivalent labor under the Cultivation System has remained one of its most obscure aspects. Van den Bosch said little enough about it, for he was sensitive to the allegation of compulsion. Moreover, he probably had little idea what was actually happening at the local leve1. ${ }^{4}$

2. Extensive powers were given van den Bosch by the King in a secret decree of June 9, 1829; at that time Elout submitted his resignation. Elout had been the highest placed critic of van den Bosch's policies, and during the months of March, April, and May 1829, the two had waged a memoranda debate. The King's decision to support van den Bosch was taken at a conference on May 23,1829 , at which time a new fundamental 1 aw for the Indies was drafted. See further, $\mathrm{J}$. J . Westendorp Boerma, Een Geestdriftig Nederlander: Johannes van den Bosch (Amsterdam: Querido, 1950), pp. 70-71.

3. The best general accounts in English of the System are found in Clive Day, The Policy and Administration of the Dutch in Java (New York: Macmillan, 1904), pp. 249-342, and J. S. Furniva11, Netherlands India (Cambridge: Cambridge University Press, 1944), pp. 115-173. These two accounts differ in interpretation rather than substance. My emphasis and interpretation is slightly different from either, but the basic facts remain much the same.

4. In the report of his accomplishments, Mijne Verrigtingen in Indië (Amsterdam: Muller, 1864), pp. 423-437, van den Bosch continuously speaks of four men (i.e., four families) per bouw of sugar or indigo, but there must have been much more labor than this drawn into the System. W. Ph. Coolhas, "Nederlands-Indië van 1830 tot 
The products delivered to the government by this scheme were to receive sufficient processing in factories or mills established with government loans to make them exportable. The processing plants were in the hands of Europeans and Chinese and worked with paid labor, although probably not entirely free labor. The processed commodities were shipped to the Netherlands in ships chartered by the Netherlands Trading Company (NHM), a government concern founded in 1825 in an unsuccessful effort to compete with English shipping. Slowly van den Bosch's System brought life into the NHM as the transportation, insurance, and marketing profits began to mount. Within the Netherlands itself the products of Java were auctioned into international channels. Gradually a new prosperity began to be felt; it was a prosperity that was supposed to have benefited everyone from the Javanese peasant to the Amsterdam merchant.

The element of the System above the level of the Javanese producer is not the primary concern of this paper, but it is well to keep in mind that van den Bosch's scheme comprised rather wide-ranging goals. In practice, there was too little concern with high ideals at the lower levels of the System, and the growing criticism of the system after the mid-1840's probably reflects with some accuracy the baleful effects which the System was having on Javanese society. ${ }^{5}$ Since much of the writing about the System has been by its opponents these failures were often drawn out of context, and there has never been an attempt (nor perhaps has it been possible) to measure the extent and form of the impact of the System.

One of the chief problems in understanding the Cultivation system derives from the fact that critics and proponents have taken it literally as a system. Actually from the moment of inception it began to function as a series of local arrangements designed to get production moving. Van den Bosch was most sensitive to the criticism that in the early years his System derived its profits from coffee cultivation which had been the mainstay of the export economy before his arrival. ${ }^{6}$ As a matter of fact, coffee remained the most profitable single export throughout the life of the System, but not for lack of efforts to

1887," Algemene Geschiedenis der Nederlanden (Utrecht: de Haan, 1955), vol. X, pp. 238-243, states that the Javanese was supposed to give up one-fifth of his land and one-fifth of his labor time for the cultivation of exportable crops.

5. G. H. van Soest, Geschiedenis van het Kultuurstelse1, 3 vols. (Rotterdam: Nijgh, 1869-71), is a rather thorough compilation of mistakes and abuses. The broader implications of the system as we11 as the mounting pressures upon the Javanese cultivator are discussed in W. M. F. Mansvelt, Geschiedenis van de Nederlandsche Hande1-Maatschappij (Haarlem: Enschedé, [1924]), vol. II, esp. pp. 48-50.

6. The anonymous book Kort Overzigt der Financiele Resultaten van het Stelsel van Kultures (Kampen: n.p., 1835), makes this point. As I have shown in my "Function of Landrent Under the Cultivation System in Java," Journal of Asian Studies, XXIII, no. 3 (May 1964), n. 27, p. 362 , the book was authored by $\bar{P}$. Merkus who was at the time a member of the Council of the Indies. He carried this argument forward in the 1840's in a letter to the Minister of Colonies, Apri1 22, 1844, Geheim, Kabinet no. 85, at the time he was GovernorGeneral. 
raise the production leve 1 of other crops, especially sugar and indigo. To change agricultural production patterns is not easy, and the early years of the System saw intensive efforts to make adjustments in the administrative and productive arrangements on Java. This was not always successful, and compromises were continually made. In the years when van den Bosch himself was in Java (1830-1834) and when his close associate J. C. Baud succeeded him as Governor-General (18341836), there was a great deal of innovation, experimentation, and variation allowed. Later efforts to regularize the System never overcame this beginning, and those who tended to see the system as a unit invariably found discrepancies which were then viewed as abuses or corruptions of the basic plan. Much of this pragmatism was of van den Bosch's creation and probably quite necessary to effect change. It may also have been necessary thereafter to bureaucratize the operation of the System.

Two essential elements of van den Bosch's arrangements to get the production of various crops started were the introduction of percentage payments and the establishment of an office of Cu1tivations. To involve the Javanese and European administrators, a percentage of the value of the crops produced in their district was paid to them; in some areas this came to amount to more than the substantial salaries paid these officials. ${ }^{7}$ The Office of Cultivations under a Director with a number of Inspectors in his charge was to supervise, regulate, and control the production of export crops, and also to make certain that the rural population was not unduly burdened, that is to say, in the parlance of the time, received proper benefits from the System. ${ }^{8}$

When van den Bosch created the Office of the Director of Cultivations in 1831 the purpose was probably somewhat less clear than stated above. Perhaps it was to be little more than an agricultural experimentation agency. The first Director of the Cultivations, J. I. van Sevenhoven, was an old Indies hand whose chief role may have been making the new chores palatable to some of the old time Residents and Regents. His agricultural advisers bordered on being charlatans, and the period he held office (1831-1833) witnessed unchecked latitude in local experimentation and/or indifference. It was under his successor, B. J. E1ias, that the office began to assume force and vigor in implementing new cultivations and at the same time inspecting for abuses while allowing local variations. Elias had been Resident in Tjirebon prior to being selected as Director of Cultivations (1833-1836). He envisioned his new function as one of maintaining an equitable balance between the interests of the government and the welfare of the population: a view which caused no small amount of disagreement with various Residents, including his eventual successor to the Directorship, W. de Voge 1 .

7. R. Reinsma, "De Kultuurprocenten in de Praktijk en in de Ogen der Tijdgenoten," Tijdschrift voor Geschiedenis (1959), pp. 57-83, provides an initial excursion into the question of the percentage payments.

8. The function of the Director of Cultivations is officially described in Staatsblad van Nederlandsch Indië, 1833, No. 73. He is to see that the System operated in accordance with the basic plan, protect the Javanese against abuses and make certain that they receive the benefits planned by the System, and direct all local efforts toward lightening the labor and increasing the income of the population. 
After 1836 the Office of the Director of Cultivations began to change. Partly this was the result of the passing of the creative period and the beginning of bureaucratized procedures. The annual Cultivation Reports which had started in 1834 became more standardized after 1836, the Directors constantly complained about being burdened with paper work and having less and.less opportunity for first-hand observations, and the reports issuing from the office grew ever further in arrears until by the $1840^{\prime} \mathrm{s}$ the annual reports appeared as much as two years late. These surface phenomena would tend to indicate that the Office of Cultivations became less and less of an integral part of the productive process in Java and grew increasingly detached from the controls and regulations which it had originally been designed to oversee.

Behind this change lay a devolution of authority within the System to the local administrators. Van den Bosch's efforts to maintain al1 decision-making power in his hands after his return to the Netherlands and elevation to Minister of Colonies in 1834 may have made it difficult for the colonial administration in Batavia to act forcibly. Also the mounting revenue needs in the Netherlands caused by the Belgian War forced al1 caution aside in an effort to expand the System. But possibly more decisive than either of these was the gradual development of convenient arrangements, in the various areas where exportable crops were grown, between Javanese administrators, European civil servants, and European and Chinese entrepreneurs and supervisors. Among these groups fortunes were made through percentage payments, underestimations of yields, and a growing private sector in the export of goods. There were fewer and fewer qualms about evading the rules of the System, heavier pressures on the cultivator, and a mounting disregard for the office of Cultivations. ${ }^{9}$

In practice after 1836 there was little possibility of the Director of Cultivations doing much to affect local cultivation arrangements. This is most cogently illustrated by the secret instructions issued to the Director of the Office of Cultivations in 1840. The Director was told not to interfere in existing local arrangements but instead to learn from the local authorities; moreover, he was to refrain from even discussing local land-rent arrangements and to avoid actions affecting work services or the socio-economic life of the Javanese villages. At most he might look about for areas in which government cultivations, especially indigo, might be expanded. ${ }^{0}$ Clearly the locus of regulation and control over the productive aspects of the System had devolved to the European and Javanese administrators in the residencies and regencies of Java. Local variations were perpetuated and expanded, and the "System" became in actuality an interlocking set of local accommodations.

9. L. Vitalis, De Invoering, Werking en Gebreken van het Stelsel van Kultures op Java (Za1t-Bomme1: Noman, 1851), pp. 21-23, takes note of the changes in the system after 1836 much in the way that I have done in this paper. Most later writers on the System have made little use of Vitalis' writings, feeling him perhaps to be too intimately tied to the founder of the System, and sharing too directly in the profits of the System, since he was assisted by the government in buying two sugar mills in Semarang in 1838. See Besluit, Gouv.-Gen., February 12, 1838, No. 11. Actually Vitalis' function as inspector of cultivations made him an astute and critical observer of many aspects of the System.

10. Geheim Besluit van den Gouverneur-Generaa1, July 17, 1840, La Ya. 
If the information and method applied in this paper have merit, it should be possible to discern differences in the operation of the System from one residency to the next, as well as variations in impact. To test this I have taken information from the annual Cultivation Reports from 1837 through 1851. In these years the content of the reports was standardized. They are to be found in complete form in the Archive of the Ministry of Colonies. ${ }^{11}$ The fact that the reports probably had little influence upon production policies during these years does not diminish their historical value. The information they contain is no more or no less accurate because of this fact; the candor of some of the statements contained in the reports was indeed probably due to the fact that the reports had ceased to be feared as instruments of discipline or control.

The Cultivation Reports have been little used in any description or analysis of the Cultivation System. Primarily this is because they were classified up to 1839 and available only to high officials in the Ministry of Colonies thereafter. After 1851 some of the essential bits of information from the Reports were incorporated in the Koloniaal Verslag, but the earlier reports were not opened to the public until about the time of the Second World War. Gradually scholars began to locate them and use them. Then another problem arose; the size and detailed nature of the statistical information made it difficult to manipulate. To resolve this difficulty I had most of the information for the years 1837 through 1851 punched on computer cards. This information was then programmed to produce the various charts, tables, and ratios with which this paper works. This paper, however, uses only a fraction of the total information.

Before turning to the actual data, I shall add a few words about the over-a11 nature and content of a typical Cultivation Report. A Cultivation Report was an annual summary of the state of cultivations in Java, and was divided into sections dealing with: Agricultural Establishments, Cinnamon, Cloves, Coffee, Corvée, Forestry, Gunny Sacks, Indigo, Livestock, Nopal and Cochineal, Pepper, Rice, Silk, Sugar, Tea and Tobacco. These sections do not necessarily appear in this order, or in any other order, and not every section appeared each year. Each section consists of text and statistical tables. The text, normally only a few pages, summarizes advances and declines, notes particular problems, and/or indicates future plans and projections. The statistical tables contain information on a residency basis. It should be noted that the residencies of Batavia (Djakarta), Buitenzorg (Bogor), Jogjakarta, and Surakarta were never incorporated into the Cultivation System and are, therefore, not included in any of the figures (including totals) used in this analysis. The statistical tables contain information on such matters as: the number of individuals and/or families involved in a particular cultivation or type of work, the land area and types of land used for a particular crop, the payments made to the population for crops grown for the government, the land-rent assessment on government fields as well as other fields, the costs of processing and transportation, and percentage payments to administrators, to mention but a few of the more

11. The Cultivation Reports are scattered in various folders of the Archive of the Ministry of Colonies which, for the years under consideration here, is located in the Rijksarchief, The Hague. Folio 3205 of this Archive contains a listing of the Cultivation Reports with their locations. 
important items. The charts accompanying the Rice sections provide the most comprehensive information on land, population, production, taxation, prices, etc. for each residency.

The set of charts in Table I shows relationships between landrent assessments and the payments made by the government for crops. These charts are first for Java as a whole (chart Ia), and then for four selected residencies (charts Ib, Ic, Id, \& Ie). The land-rent was the largest tax item for the rural Javanese as well as for the government; it was not the only tax, but it was the one most directly related to the cultivations. Payment for crops grown for the government was far from being the only source of monetary income for the Javanese villager, but it represented, more than any other source, the benefit which the System was supposed to bring to the Javanese.

It will be immediately apparent that the total 1and-rent assessment for the whole of Java on all cultivated fields generally ran below the payments made for al1 crops, including coffee, which were grown under the government's Cultivation System. The four selected residencies show markedly diverse patterns, and two of them, Semarang and Surabaja, have land-rent assessments which continually exceed the total payments for crops. The assessment on fields planted for the government ran continuously below the payments made for the crops grown on these fields, principally sugar and indigo, and, with the exception of Semarang, this was a rather large difference. This difference should represent the profit to the Javanese population directly involved in the cultivation of government crops on their lands if only the two elements represented on these charts are taken into account.

It will also be seen from Table I that the land-rent assessment rose during the late $1830^{\prime} \mathrm{s}$ and early $1840^{\prime} \mathrm{s}$, and began to level off, and even dip, after the middle of the 1840's. The payments made for government cultivations except coffee show a similar, albeit less pronounced, tendency. The inclusion of the coffee payments tends to diffuse this correlation, for coffee yields ran in natural cycles quite independent of governmental action. The charts reflect statistically what every account of the Cultivation System has already indicated: namely, that the System ran into trouble in the mid 1840's. These troubles are genera11y attributed to overextension, and their solution was sought in adjustments of 1 and-rent assessments and reduction of areas in government cultivation. The charts for Bagelen (Ib), Semarang (IC), and Tjirebon (Ie) show a sharper than normal adjustment; this corresponds with the reported severity of the problems in these particular residencies.

The charts in Table II are both more complex and less precise. than those in Table I. Essentially they represent a graphic relationship between the number of families and the area of land involved in government cultivations. To present this relationship graphically, the number of families liable to cultivation services and the extent of land used in the government cultivations are expressed in percentages of the total number of agricultural families and the total area of cultivated land respectively. The charts are for all of Java and for the same four selected residencies, and provide information for total crops as well as separately for indigo, sugar, and coffee. Since coffee was not grown on land otherwise cultivated, there is no line on the coffee charts for the percentage of cultivated land.

The imprecision of these charts is caused by the difficulty in obtaining accurate information about numbers of people or families and 


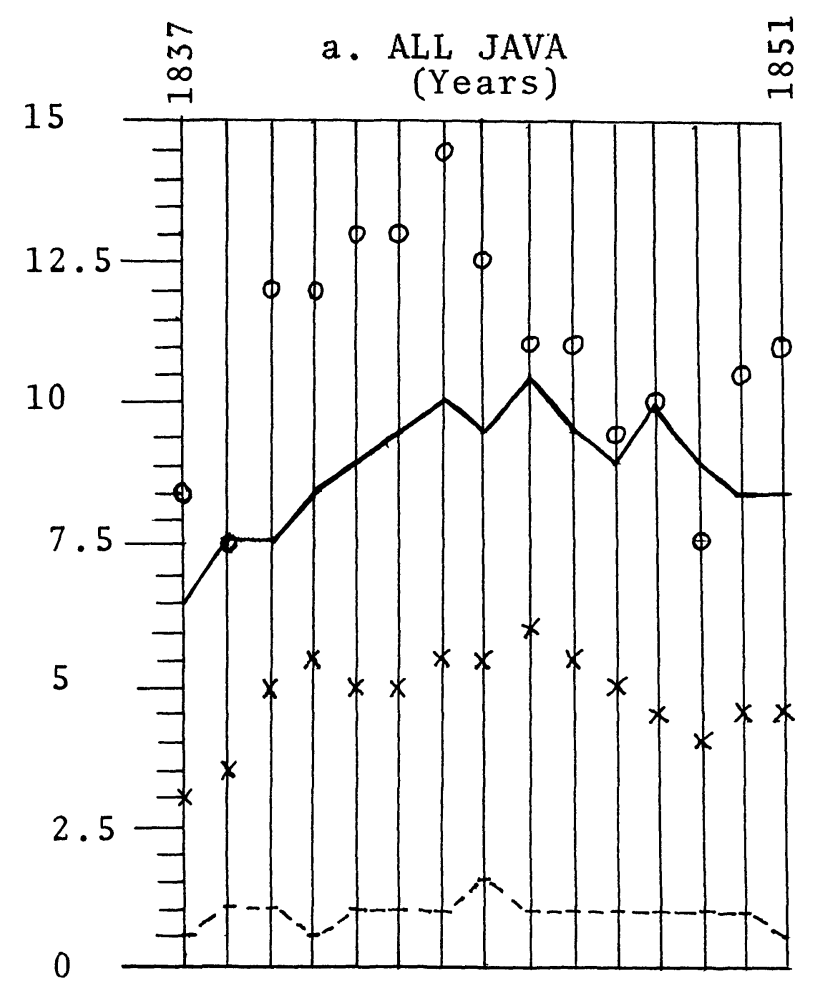

Purchase price paid to population for:

o a11 government cultivations;

$x$ a11 government cultivations except coffee.

Gross 1 and-rent assessment:

$\Gamma$ on a11 cultivated fields (inc1. govt.); -- on fields planted for the government only

b. BAGELEN

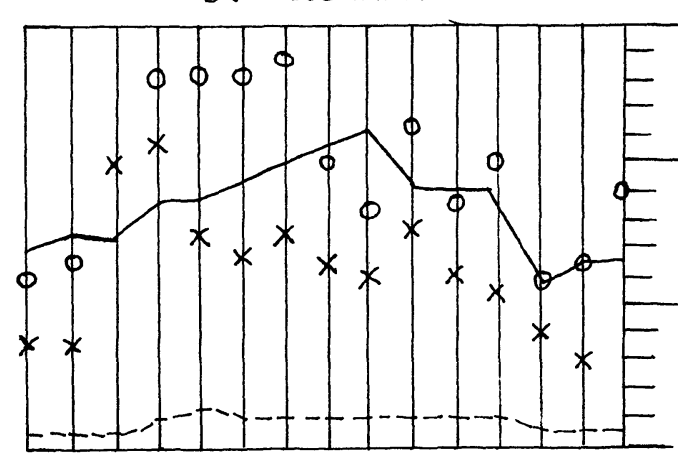

d. SURABAJA

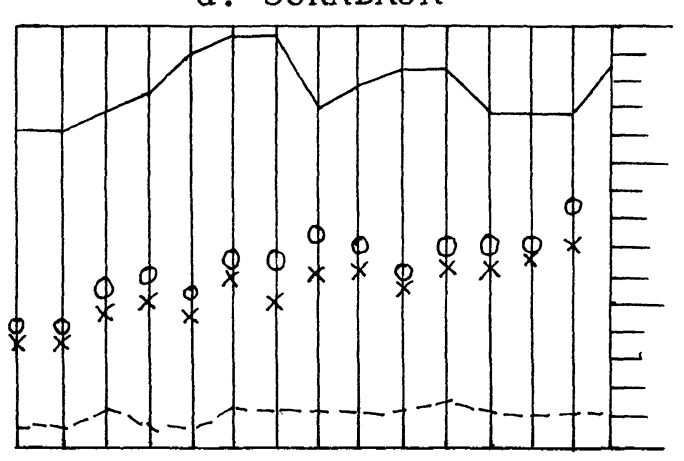

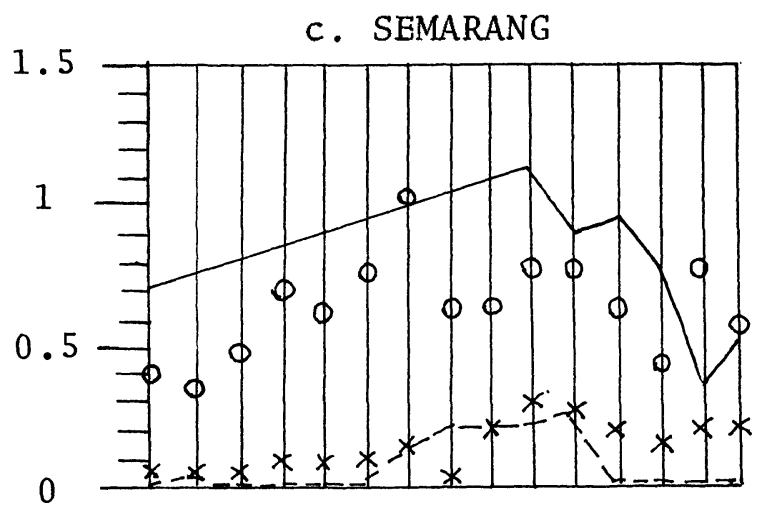

e. TJIREBON

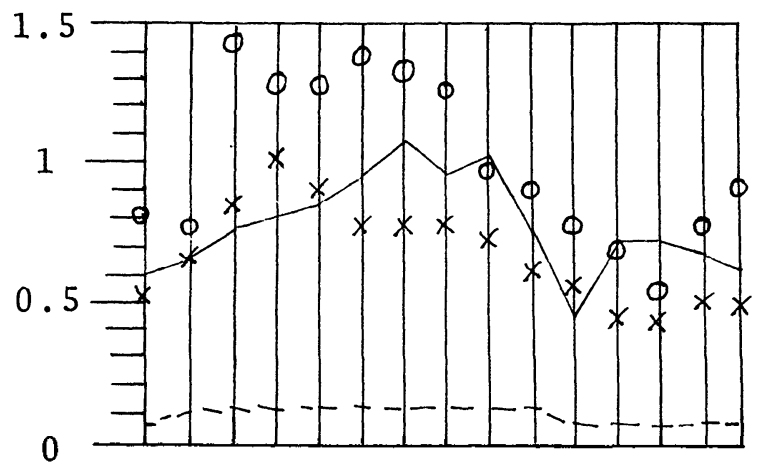


TABLE I I

Percentage of agricultural families involved in government required work for particular cultivations.

Percentage of sawah and tegalan fields used for cultivation of government crops.
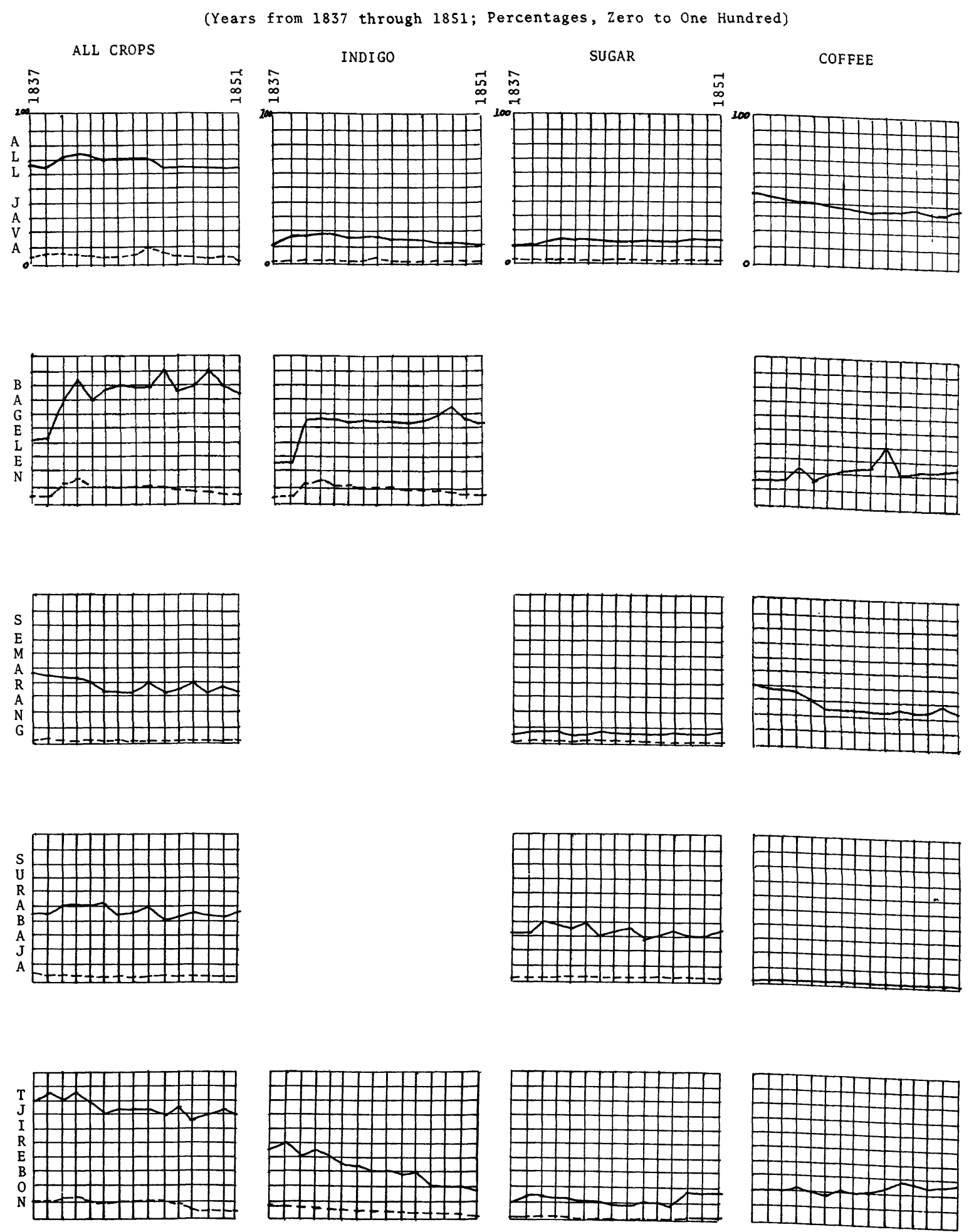
areas of land under cultivation in Java at the time with which we are concerned. Census and cadastral surveys were unknown; all figures were based on reportings from village officials to higher authorities. Virtually everyone who has used nineteenth-century Javanese figures has expressed cautions and doubts, and quite correctly so. It appears from my work with these statistics and by comparing them with spot checks and demographic regressions that a fairly constant divergence factor of 25 per cent below the actual amount can be applied to both the total number of families and the total area of 1 and. The basis of this correction factor is explained in the appendix to this paper (see below, p. 107). Suffice it to note here that the charts in Table II are based on the actual figures as given. If the correction factor were applied it would lower the percentage of families and land used in government cultivations below that shown in the charts.

From the graphs in Table II it will be evident that the portion of cultivated land used for government cultivations was not a large portion of the total. Throughout the period government cultivations remain at about 5 per cent of the total land under cultivation. This is probably on the high side since this land was apt to be more accurately measured than was general village land in cultivation. The porportion of land in government cultivation runs higher in Bagelen and $T$ jirebon, a feature which is accounted for by the extent of 1 and used in indigo cultivation.

What appears remarkable in light of the small land area is the high percentage of agricultural families involved in government cultivations. It will be noticed from the upper left hand chart in Table II that the percentage of agricultural families involved in government cultivations for all of Java is in excess of 70 per cent for much of the period. For all of Java somewhat more than one half of these families were involved in coffee growing. But in Bagelen and $T$ jirebon the involvement in indigo production was also large, and in Surabaja sugar cane cultivation accounted for the largest portion. This high human involvement in the System begins to shed some light on the hitherto rather obscure element of labor service. However it was managed, there was a heavy concentration of labor brought to bear upon rather limited areas of land. Accounts of the time would lead to the conclusion that this labor force did not all appear at once, that there arose a group of people who for payment performed work services for others, and that not all the persons or families listed actually did field work. In general, the poor and propertyless seem to have borne the brunt of the work, but this had compensations which were not always expressed in monetary terms. ${ }^{12}$

The high proportion of agricultural families involved in government cultivations would tend to provide some explanation for the extremely low per capita payments made under the System for produce from government fields, for not only was the labor input far too large for even the most optimistic production schemes, but the large labor force was often wastefully used. Somewhat less directly evident, but

12. Day, Policy and Administration, p. 267, speculated on the emergence of a destitute class under the system. His evidence for this seems to rest entirely on van Soest's Geschiedenis, which would certainly indicate that all was not right with the System, but which would not give a very positive notion of the emergence of such a class at this time. 
probably true nonetheless, is the frequently made observation both during and after the years of the Cultivation System that it encouraged communal landholding rather than individual holdings. Both the high human involvement in some villages and the rotation of lands in sugar, indigo, and tobacco areas would support this tendency, which was in any event a rather normal state of affairs for many parts of Java.13 Whatever the truth of these contentions, it seems quite evident that the numbers of persons involved in the System, directly or indirectly, were extremely large, and that it is obviously in this area, rather than in the extent of land used, that the System had its most noticeable effect in Java. Where these figures run especially high, as in Bagelen and Tjirebon, there are noticeable social effects as will be shown presentiy.

It would probably be useful to bring these labor figures somewhat into perspective by providing a brief explanation of the manner of cultivation and delivery used in the three major crops listed here: coffee, indigo, and sugar. The various forms of labor activity and possible extra compensations will not alter the figures, but may make them more understandable.

Coffee deliveries for little or no compensation had been imposed upon various districts in Java long before the Cultivation system was introduced, and in a strict sense coffee was not included in the schemes of van den Bosch. However, in a practical way it was not possible to exclude the largest revenue-producing crop from a tota1 economic plan, and the Director of Cultivations included coffee in his reports from the outset. Van den Bosch did undertake to reform the existing system of coffee deliveries first by making monetary payments immediately upon delivery and directly to the cultivator or person who delivered the coffee rather than to headmen, and second by increasing the number of collection-payment stations, thereby reducing the transportation distance for the coffee growers. ${ }^{14}$ Almost al1 persons, however they felt about other aspects of the Cultivation System, regarded these reforms as beneficent and clearly in the economic interest of the Javanese villager. In portions of the Preanger Regencies the custom of delivering coffee in lieu of the paddy assessment continued.

Coffee was grown in three ways, namely, in gardens, forests, and hedgerows. Only the agricultural families designated for work in gardens and forests are included in the totals of the Cultivation Reports and in the charts in Table II. Coffee gardens were planted in foothill and upland areas on land not used for other cultivations. Forest coffee consisted of plantings in the midst of forested areas,

13. A most perceptive insight into the nature of communal landholding and the regulation of village affairs in the middle of the nineteenth century is given by J.H. F. Sollewijn Gelpke, Naar Aanleiding van Staatsblad, 1878, No. 110 (Batavia: 1901), pp. 7-9 and 24-28.

14. The basic coffee reforms came about through a resolution of August 8,1832 , No. 35, and later decrees. In the formulation of this policy van den Bosch had worked closely with Merkus; this was one of the few occasions on which the two men cooperated in these years. See S. van Deventer, Bijdragen tot de Kennis van het Landelijk Stelsel op Java (Za1t-Bomme1: Noman, 1865-66), vol. I I, pp. 526-527. 
where the coffee often did very we11. For the planting and maintenance of more than 200,000,000 coffee trees in Java during the 1840's there were between 400,000 and 500,000 families designated as 1aborers. Constant planting was necessary, and between two and ten million new trees were planted annually, either to replace old trees or on newly opened areas. Whole families worked in various phases of the coffee growing; the work was generally seasonal. The remoteness of the coffee gardens and the primitive transportation system made the work more arduous than it would otherwise have been. The payment of seven to ten guilders per picul was great enough to provide some profit for most families, though this varied: in some areas as few as 75 trees would yield a picul of coffee, while in other locations it took more than 300. Hedgerow coffee was grown along roads and paths in kampong areas as an extra source of income for villagers throughout Java.

Sma11 amounts of indigo had been grown in Java since time immemorial, but extensive cultivation and preparation for export were introduced during the Cultivation System. The indigo plant was grown on non-irrigated fields, frequently those otherwise used for dry rice or secondary crops. From all reports, indigo growing and preparation became the most detested of the cultivations for the Javanese. There are three obvious reasons for this. The indigo plant exhausted the soil. After a few years neither indigo nor any other crop would grow on the land, and new areas, further from the village, had to be opened. Second, the preparation in small factories involved a fermentation process which required wading and sloshing in the vats with resultant discoloration of the skin. While such work was paid extra, it was not free of compulsion. Third, the payments to field workers were small to begin with, but the vast numbers of persons used in the cultivation made the individual payment minuscule. Indigo was not very profitable to the government either, and by the mid $1840^{\prime} \mathrm{s}$ the area in cultivation was cut back--many of the workers were turned into coffee growers--and gradua11y indigo planting was almost totally abandoned.

Sugar, also, had been grown in Java before 1830, chiefly around Batavia and in a few areas of East Java. The Cultivation System, however, extended the crop throughout the northern coastal plains of Java. Where it flourished, as in the Surabaja-Pasuruan area, it provided the basis for some prosperity for Javanese and a greal deal more for European and Chinese millers and exporters. Where it grew with difficulty and with low yields, as in Central Java, it created much work and less than the anticipated profits. Where it failed to grow, as in Bantam, it was soon abandoned. So far as the Cultivation System was concerned, the only obligation of the villager was to plant, tend, and cut the cane; it is this much of the process that is shown in both the payment and the number of families shown in the charts of Tables I and II. But clearly more had to happen before sugar could be exported. Such processes as transporting the cane from the field to the factory, working in the factory, and again transporting the refined sugar to the wharf, were all compensated, aside from the payments for the raw cane. These additional payments do not appear in the figures used here. Generally, transportation was arranged on a contractual basis with individuals, and there began to appear an independent group of transport entrepreneurs. Factory work was not always voluntary, even though additional pay was given; frequently factory labor was supplied through arrangements with village headmen, not unlike the compulsion used for field laborers.

Sugar cane was grown on irrigated rice fields which were taken out of production for a year or eighteen months in order to accommodate 
the new crop. The growing cycle came, in many areas, to be accommodated within the rice pattern of production, and as village lands were extended and new areas brought into irrigation, there developed vast tracts of alternating paddy and cane cultivation. In such areas more than one-fifth of a village's lands were devoted to cane; this brought about very complicated land swaps. Also in these areas the villages became heavily dependent upon the extra monetary income from the various stages of growing and processing the sugar; this dependence produced social and economic changes within the village which were difficult to control either from within or from without.

To carry forward our analysis of the charts in Tables I and II, I would like to introduce two further sets of relationships based on the statistical data from the Cultivation Reports. Table II shows the percentage of agricultural families employed in various cultivations during the years 1837 through 1851 , but the charts tell us nothing about the absolute total of agricultural families as it might have changed over the period in question. If we express this rise and fall of the number of agricultural families at the beginning, mid-point, and end of our period as percentages of the numbers at the beginning of the period, we are presented with the following figures:

\begin{tabular}{|c|c|c|c|}
\hline & Beginning & Mid-Point & End \\
\hline Al1 Java & $100 \%$ & $109 \%$ & $103 \%$ \\
\hline Bagelen & $100 \%$ & $98 \%$ & $69 \%$ \\
\hline Semarang & $100 \%$ & $115 \%$ & $97 \%$ \\
\hline Surabaja & $100 \%$ & $116 \%$ & $140 \%$ \\
\hline Tjirebon & $100 \%$ & $107 \%$ & $80 \%$ \\
\hline
\end{tabular}

Nor do the charts in Table II provide us with information about the relationship between the total number of agricultural families and the total amount of land in cultivation. Using again the beginning, mid-point, and end of our fifteen year period, and dividing the total units ${ }^{15}$ of land in cultivation by the total number of agricultural families (obtaining thereby the average amount of cultivated land per agricultural family), we obtain the following set of figures.

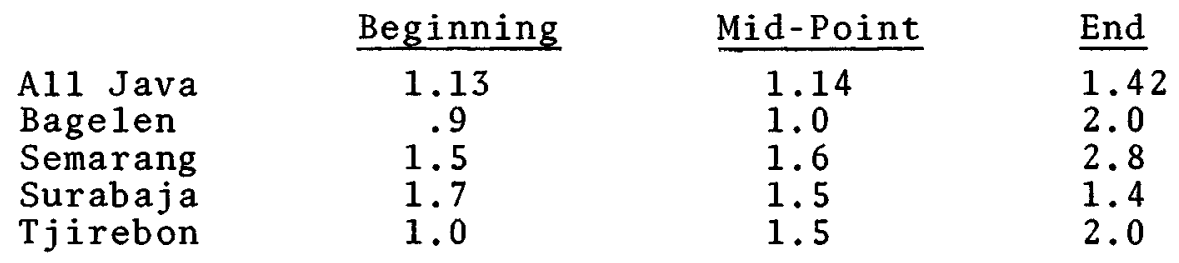

These figures give an indication both of rising population and increased amounts of cultivated land for all Java. Contemporary accounts constantly refer to the opening of new lands through the extension of irrigation channels, the draining of coastal swamps, and the clearing of new lands. It would appear that the amount of land in cultivation increased somewhat more rapidly than the number of agricultural families, but not too much should be made of this because of the difficulty in enumeration. The labor involved in opening and

15. The unit of land measurement was the bouw (bau or bahu) which varied in size from one part of Java to another, but which was standarized in the Cultivation Reports as an areal measurement of 500 square rods. 
improving agricultural lands was in large part included in the cultivation work for which the families in Table II were designated. This could be extremely hard work, and was reflected in the compensation and production patterns only at a future date if at a11.

The number of agricultural families seems to have increased slowly for all of Java, but to have decreased in three of the four residencies examined here. Contemporary accounts frequently speak of villagers, sometimes whole villages, moving, so the trends shown here need not be surprising. Part of this mobility was undoubtedly into towns and cities, which would mean statistically that the migrant family would drop out of the agricultural count but would eventually be picked up again in the total population count. Some of the movement was into unoccupied or formerly abandoned areas, principally in East Java, which had been depopulated in the wars of the late eighteenth and early nineteenth centuries culminating in the Java War of 1825-1830. The population line, 1ike the landrent 1 ine in Table $I$, moves slowly upward to the mid 1840 's and then declines slightly. The poor harvests and accompanying epidemics of the $1840^{\prime} \mathrm{s}$, especially severe in the Semarang-Demak-Rembang area, are generally cited as a cause of this trend, and they undoubtediy had an effect. The extent of family mobility, however, probably also put a strain on the primitive counting methods of the time.

From an examinination of the trends of population and 1 and in the four selected residencies, it appears that Surabaja runs counter to the other three. In regard to the number of agricultural families it is the on $1 y$ residency to show an increase during the period.

Semarang and Tjirebon show a rise into the mid-1840's, then a decline below the beginning point. Bagelen displays a constant decline throughout the period.

These trends tend to confirm, and to be confirmed by, the charts in Tables I and II as well as by the reports of the time. In Bagelen, for instance, the burdensome nature of the indigo cultivation has already been noted. It is not surprising that families and villages left the area or made themselves scarce. The continuously heavy labor involvement shown in the Bagelen charts in Table II meant, of course, a steady decrease in absolute numbers since the number of agricultural families was absolutely decreasing. The decreasing 1 and area devoted to indigo in Bagelen (Table II) reflects this trend too, but the over-al1 decline in the number of agricultural workers is less than would be anticipated in Bagelen because of transference out of indigo into the expanding coffee cultivations.

One feature of the Semarang chart, Table Ic, which needs some clarification, is the unusual rise in the assessment of fields planted for the government in the mid-1840's. Coming at a time when epidemics and famine were prevalent in the area and total agricultural families were declining, this may seem very strange indeed. Indeed, it should for it reveals a clear case of maladministration in which the local Resident and his staff were attempting to cover up a mismanaged situation by throwing additional burdens on the assessments on government fields. Assessments on government fields rose to 27 per cent of total assessments with less than 2 per cent of the total cultivated area planted for the government. This was a desperate effort to cover losses on abandoned fields caused by population movements and deaths, and to offset losses from a futile and costly effort to introduce tobacco cultivation. Chart Ic shows some rather hasty readjustments in the residency after 1847; tobacco areas were reduced, land-rent 
assessments were lowered, large irrigation schemes were undertaken, and the labor involvement in sugar cane cultivation was slowly increased. The local administration, both European and Javanese, was also shaken up.

In both Semarang and Tjirebon the statistical patterns and the contemporary reports have a certain similarity. The introduction of indigo in $\mathrm{Tj}$ irebon and sugar cane in Semarang did not go especially we11. Extensive draining of swamps along the coast and opening of new 1 ands occurred in both areas. Lack of profit and heavy labor requirements drove people off the land and out of compulsory government service. Apparently the movement off the land was principally into the major towns and city of each residency, for the total population in both regions remained rather constant despite the marked decline in agricultural population. This is quite unlike the Bagelen situation where both total population and agricultural population declined.

Only in Surabaja does the number of agricultural families increase constantly and sharply, so sharply that an inward migration can be the only explanation. The lighter than average involvement in government cultivations, as shown in Table II, and the prospering sugar industry would appear to be significant contributing factors. The lack of any reported food or disease crisis in the Surabaja area during this period must also be noted. The increase shown in Surabaja is similar to the patterns for the residencies of Pasuruan and Besuki, both expanding sugar areas. The residencies of Kediri and Madiun also show a similar, albeit less pronounced, trend. By contrast, all resjdencies in Central Java seem to have lost agricultural population. ${ }^{16}$

Turning to the relationship between the area of cultivated land and the number of agricultural families, we note from figures on p. 101 that the area of 1 and per family was gradually increasing throughout the period for all Java. This increase is reflected in exaggerated fashion in three of the four sample residencies; only Surabaja is moving in the other direction. The over-all increase for all Java is about 125 per cent while that for Semarang is 185 per cent, Tjirebon 200 per cent, and Bagelen 220 per cent. This is naturally related to the movement off the land in these three areas which, along with the addition of newly opened lands, meant that there was increasingly more cultivated land per family. Or, seen from another perspective, there were less people to work more land as time went on. Surabaja shows the steady decrease in the area of cultivated land per agricultural family to be expected in light of the inward migration. Also the actual expansion of cultivated lands in Surabaja was less than in the other three residencies. Moreover, the growing reliance of agricultural families in the sugar

16. The statistical information for all residencies has been worked out, but is not included in this paper. Where reference is made to contemporary accounts, the text portion of the Cultivation Reports is generally meant. However, such accounts as van Soest's Geschiedenis and van Deventer's Bijdragen are compendia of details about famine and disease (attributed to the System), abuses, brutalities, and stupidities which led to the abandonment of certain areas as well as less sizeable movements of populations. 
producing areas upon land rentals to sugar producers and upon paid work in the sugar industry, may well have made it possible to concentrate more people on smaller amounts of land.

From all of this it would appear that the amount of land available was perhaps less important to an agricultural family than the amount of imposed 1 abor required by the government and/or the profitability of particular types of work. The availability of agricultural land in Bagelen, Semarang, and Tjirebon may have been a contributing factor in the individualization of landholding which is noted in these areas later in the century. While the interpretation of the data produced by the investigation launched in the 1860 's into Javanese rights in land awaits careful analysis, it is quite evident that communal holdings were strongest in East Java and the interior regions of Central Java, while individual landholdings arrangements prevailed in West Java and along the central north coast. ${ }^{17}$ The rather easy availability of land in Bagelen, Semarang, and $T j i$ rebon may have led to concentration of landholding by families which could either escape or manage the imposed services that accompanied control of land. Administrative families as well as village headmen were freed of such obligations, and it is possible that for such groups their privileged position would allow a gradual shift in economic patterns.

An interesting question which our data does not touch upon but which seems relevant to understanding the relationships expounded here, is the extent to which cultivation services were turned to other ends and the extent to which other service obligations continued. Technically both were violations of the system as originally conceived, but both happened and seem to have become regularized. Large government projects such as road works, factory construction, and the building of fortifications continued to draw on labor which was levied under corvée arrangements supposedly equated with, not imposed in addition to, cultivation work. Forced labor imposed by village headmen and higher officials, except for village guard duty and loca1 maintenance, was supposed to cancel out cultivation obligations, and to be specially provided for from particular villages which were freed from cultivation work. But there are many indications that large amounts of labor were used on personal projects by both European and Javanese civil servants. This question is too complex to be unravelled here. Suffice it to note that the burden of obligatory service could mount up considerably in some areas, and, quite apart from any particular crop or type of land usage, the personal quirks of the local administration which had virtually a free hand in such matters was of considerable importance in determining the quality of 1 ife of the agriculturist.

A number of observations should be made to clarify certain aspects of the problems raised here. Van den Bosch had assumed

17. Eindresumé van het Onderzoek naar de Rechten van den Inlander, 3 vols. (Batavia: Ernst, 1876, 1880, and 1896), makes the 1oca1 variations in landholding arrangements quite explicit. The report was so long in preparation that it had little effect upon the land conversion arrangements toward individual holdings which the government started in the late nineteenth century. The wealth of substantive data contained in this report has hardly been touched by scholars. 
that his plan would bring increased welfare and prosperity to the Javanese. In the main, despite shortfalls in some areas, the System did that. By all material bases of calculation such as area of land under cultivation per family, amount of livestock per family, and availability and price of basic food commodities it would appear that material well-being was growing more rapidly than the population during the period under consideration here. But this is a very generalized observation and says nothing about the manner in which these material gains were distributed among the population.

From Table I it is clear that the payments made to the population for crops grown for the government were more than enough to pay the land-rent assessment on the lands on which government crops were grown. But that was not the purpose of the System; it was supposed to provide enough to pay the total land-rent assessment. In a few localities this occurred, but it was more the exception than the rule. Moreover, if we view the amount of payment for crops in relation to the number of agricultural families involved, then the payment per family was minuscule. But it is not at all clear that payments were made on a per family basis. In some areas such individualized payments were introduced by European administrators, but much more common was payment on a village basis, or, to put it differently, a reduction in the land-rent owed by the village by the amount of the crop payment. In actuality, then, many families received no benefits unless they were included among the village landholders. There are indeed indications that in many villages landholding rights were extended to a broader segment of the population under the Cultivation System than had previously been the case. Such indications lie behind the assumption, probably correct, that the System encouraged communal landholding arrangements in many areas.

It is perhaps not surprising that the land-rent assessment on fields planted for the government was on the average higher than on the remaining fields. Chart Ia shows that the land-rent assessment on government fields ran at about 12 per cent of the total, while the extent of such fields, as shown in the upper left hand chart of Table II, was generally less than 6 per cent of the total cultivated area. The statistics are again confirmed by contemporary observations which tell us that fields planted in sugar cane were always assessed at the highest rate regardless of what their classification might have been when planted in paddy. 18 It also follows logically that since fields planted for the government were more accurately measured and supervised the assessment discrepancy would be even greater.

There is probably little doubt that such matters as described here ran counter to the original plan of van den Bosch, but they did exist and did grow worse as time went on. They form an essential aspect of the pressure of the System upon the Javanese cultivator and the tendency of the System to effect social changes in Javanese society. Van den Bosch undoubtedly succeeded in raising the material level of Javanese society. The system in its own way undoubtedly bestowed privilege and benefit upon a small segment of Javanese society, but there was very little done to promote the sense of enterprise and personal endeavor among the Javanese. That was not, of course, van den Bosch's purpose. Javanese society was supposed to

18. R. W. J. C. Bake, Kunnen en Moeten er Veranderingen Gebragt Worden in het Kultuurstelsel op Java (Utrecht: Dekema, 1854), p. 22. 
remain constant and content; it was not meant to develop any dynamism. Moreover, there was an underlying assumption that the Javanese cultivator was not influenced by normal economic stimuli--an assumption that would appear rather far off the mark if the evidence presented in this paper has any validity. Whatever the aims of the System in preserving Javanese society in stasis, they were not successful. Javanese society did change, did develop new social and economic relationships, and did apparently undergo population shifts. It is also a fact that the profits from the cultivation of crops for the government which the Javanese did not make were being made by others, namely the European and Chinese mill owners, importers and exporters, and especially, of course, the government itself.

The period of the $1830^{\prime} \mathrm{s}$, just prior to the years covered by the statistical evidence used in this paper, seems to me a most critical time in the development of the System. In the early 1830's there had been some efforts to involve the Javanese cultivator more directly in the System. Labor arrangements, for instance, were originally conceived as contractual rather than forced. This did not work well, partly due to impatience and pressures for money from the European side, partly due to socio-economic disabilities among the Javanese. In some areas, such as Djepara, there were early efforts to involve the Javanese in the processing side of the System. These efforts too were soon abandoned, owing to stronger Chinese capital, on the one hand, and, on the other, failure to maintain quality control. ${ }^{19}$ Schemes to involve some of the Javanese prijaji upper class in milling and production contracts also failed. After 1836 no further efforts were made in this direction, and the role and function of the Javanese was relegated to what seemed to work best, namely traditional authority controlling unthinking labor. The system, as I have said above, became entrenched in local arrangements, and as it began to show profits, it became less and less possible to tamper with its production features. There was by now no longer room for the Javanese, other than the administrators, to seek a future within the cultivation aspects of the System. There was no device within the System for absorbing the socio-economic or cultural changes which emerged. Only in fringe areas was this possible. Transportation contracts, arrangements for delivery of subsidiary materials, supervisory functions in fields and mills, and other types of jobs developed around the government cultivations. For many others movement into the towns and cities provided an entry either into paid employment or into an expanding. internal commercial sector which provided commodities for the growing market economy on Java. This market economy was in large part expanded through the growing communication network and the increased monetization of economic life made necessary by the System.

From an economic point of view the growing profits to individuals and to the government produced by the System came largely from more efficient processing of sugar and the continued marketability of coffee. This could occur without altering arrangements for cultivation or payment with the population. The charts in Table II indicate quite clearly that the area of land under government cultivation was diminishing, while the number of families with an obligation for cultivation service remained constant. It would appear that the size of the labor force bore little relationship to the economic functioning

19. R. Van Niel, "The Regulation of Sugar Production in Java, 1830$1840, "$ in R. Van Niel, ed., Economic Factors in Southeast Asian Social Change (Honolulu: Asian Studies Program, University of Hawaii Press, 1968), pp. 91-108. 
of the System. I suspect that the amount of available labor that became tied to prestige functions of Javanese and European administrators became ever greater. By the end of the period which we are considering here there was probably more abuse in the area of diverting services to personal ends than there was in the way of overwork in the actual cultivation of crops.

\section{Conclusion}

Most of the statistical evidence presented in this paper has tended to confirm and substantiate the accounts of the Cultivation System as obtained from other sources. We have certainly not presented a radical revision of the generally accepted story. Moreover, this type of evidence seems most convincing and is most illuminating when used in conjunction with other kinds of materia1. At most, the data has highlighted certain developments such as the extent to which the population was involved in the System and the degree of population mobility in Java. These are not new concepts, but the fashion in which they are presented here may make them more rigorous, and by so doing may place some of the changes in Javanese society in sharper perspective. This type of supporting and reinforcing role is probably the most that should be hoped for or expected.

It is my feeling that this is sufficient to warrant a continuation of the method of inquiry. Information on rice prices, paddy yields, wages, livestock, and many other items are available in the cultivation Reports for the period covered in this paper. Much of this type of data continued to appear in later periods in the Koloniaal

Verslag. Some records below the residency level may still be in existence and may become available to future historians.20 Such records can provide exciting insights into local variations, and can perhaps advance our understanding of the process of social change. Historians will hopefully be able to use the records as a whole to tell a story of social, economic and cultural change in Java which wi11 include the Javanese population whose own records of mundane events scarcely exist. The present effort to do this is rather gross, in keeping with the nature of the evidence, but one can hope for future refinements.

\section{Appendix}

The Cultivation Reports for the years covered here (1837-1851) contain figures on total population on a residency basis. The total population for all reported residencies rose from $6,282,848$ in 1837 to $7,386,802$ in 1851. These figures were derived from village and district reports compiled by local officials whose interests lay in under-reporting, but whose capacity to do this was limited by sight estimates by European and higher Javanese officials. The residencies of Batavia (Djakarta), Buitenzorg (Bogor), Jogjakarta, and Surakarta were not included in these figures. It was customary among officials

20. R. Van Niel, A Survey of Historical Source Materials in Java and Manila (Honolulu: University of Hawaii Press, 1970), p. 12. 
at the time to estimate the population of these excluded areas at about two million persons. If this amount is added to the population figure for 1851 we achieve a total population for all Java of about $9.3 \mathrm{milli}$ on persons which is very close to the officially reported figure of 9.5 million given in the Koloniaal Verslag for 1850 .

I cannot explain why $\mathrm{Dr}$. P. Bleeker, whose investigations into the population of Java began in the mid-1840's and whose figures are used by all demographers for this period, made no use of the figures in the Cultivation Reports. ${ }^{1}$ The Cultivation Reports do not show as high a rate of growth as Bleeker and others tended to assume, but this more moderate growth rate for the period under consideration seems to accord more closely with the feelings of contemporary demographers about Java's population during the early nineteenth century.

No one, then or now, would regard any of the nineteenth century figures as accurate. The question is, how inaccurate are they? Through working backwards from later data, Breman estimates that the population of Java in 1850 must have been about $12.5 \mathrm{million}$, while Peper prefers a figure closer to 13.1 million. ${ }^{22}$ The difference is attributable to various estimates about the rate of population growth in the latter half of the nineteenth century. Widjojo prefers to make no estimates for lack of accurate evidence (for which he cannot be blamed), but questions any population growth to speak of in the nineteenth century. This latter supposition is completely unsupportable. It seems to rest on nothing more than an exaggerated reading of Gonggrijp, whose already exaggerated account of the effects of the Cultivation System is generally recognized as an overreaction by an economic liberal to a system of restriction and state control The fact is that the studies of Breman and Peper provide us with some estimates which, if used cautiously, can give us a working model of Javanese population configurations in the nineteenth century.

If we accept Breman's figure of 12.5 million persons as the approximate population of Java in 1850 , and take the figure of 9.3 million as the sum of the total obtained from the Cultivation Reports and the uncounted residencies, for about the same date, we note that the latter figures are about 75 per cent of the former. Van der Wijk reports on a population reassessment check in Tjirebon in 1844 in which the population proved to be 145,000 instead of a reported 105,000 ; this would mean that in this instance only 72 per cent of the actual total had been reported. ${ }^{24}$

21. P. Bleeker, "Statistisch-Ekonomische Onderzoekingen en Beschouwingen op Koloniaal Gebied: Over de Bevolkingstoename op Java," Tijdschrift Voor Nederlandsch Indië, nieuwe serie I (1863), pp. 193-194.

22. J. C. Breman, "Java: Bevolkingsgroei en Demografische Structuur," Drie Geografische Studies over Java (Leiden: Bri11, 1963), pp. 252308, esp. 267-269; Bram Peper, Grootte en Groei van Java's Inheemse Bevolking in de Negentiende Eeuw (Amsterdam: AnthropologischSociologisch Centrum, Publikatie Nr. 11, 1967), esp. pp. 112-119.

23. Widjojo Nitisastro, Population Trends in Indonesia (Ithaca: Corne11 University Press, 1970), chapter 3 .

24. H. C. van der Wijck, Eenige Beschouwingen over Java (Arnhem: Nijhoff, 1851), pp. 42-48. 
The Cultivation Reports also provide information on the extent of 1 and area under cultivation. Again these figures are derived from village headmen and local officials, and again there were clear advantages to under-reporting. Dutch officials in Java at the time were quite aware of this practice, and made some spot checks to determine how far off reported land areas were from the reality. One such check in $\mathrm{Tj}$ irebon in 1842 led Governor-General Merkus to report that the $1,515,436$ bouw reported in that residency was about 500,000 bouw short of the mark. ${ }^{25}$ The reported amount was thus about 75 per cent of the actual total. In 1836 a random sampling of villages in Tjirebon, Pekalongan, and Tegal showed that a reported cultivated area of 990 bouw was in actuality 1380 bouw--meaning that only 72 per cent of the true amount of cultivated 1 and was reported. 26

It should be noted in both instances that this factor of underreporting ranging from 72 to 75 per cent of the rechecked totals for both population and cultivated land, works only for rather large aggregates. It is often not relevant to figures for a single village. For the large aggregates, however, I have found it to be fairly consistent for the period covered by this paper.

Whatever the merits or demerits of applying any such factor to the adjustments of statistical errors in the pertinent data contained in the Cultivation Reports, it should be noted that this was not done in the present analysis; here all calculations are based upon figures exactly as contained in the Cultivation Reports.

25. Letter from Gouv.-Gen. P. Merkus to the Minister of Colonies, dd. Buitenzorg, April 22, 1844, Geheim, Kabinet no. 85. Archive, Ministry of Colonies.

26. Van Deventer, Bijdragen, vol. III, report of P. F. Clignett, pp. 45-63; see esp. the chart on p. 64. 